\title{
Counterfeit Luxury Goods Online: An Investigation of Consumer Perceptions
}

\author{
Anita Radón \\ The Swedish School of Textiles, University of Borås \\ SE- 501 90, Borås, Sweden \\ E-mail: anita.radon@hb.se
}

\author{
Received: December 3, $2011 \quad$ Accepted: January 12, $2012 \quad$ Published: April 1, 2012 \\ doi:10.5539/ijms.v4n2p74 \\ URL: http://dx.doi.org/10.5539/ijms.v4n2p74
}

\begin{abstract}
This paper looks into why consumers choose to purchase counterfeits online and if and how this affects brand image. It seeks to explain what it is that is prevailing in choosing to purchase counterfeit merchandise online as oppose to genuine merchandise or generic goods online as well as through traditional distribution channels. Online interviews with consumers of counterfeit merchandise have been conducted. Findings: The interviews have shown that the most important factors that consumers of counterfeit merchandise online consider are conspicuous value and price. This paper also shows how luxury brands own websites can be a liability adding in online fake sales. This paper only explores actual consumers of counterfeit merchandise; a further study should focus on online consumers of genuine goods and their perceptions toward online sales of counterfeits.
\end{abstract}

Keywords: Luxury brands, Counterfeits, Internet, Conspicuous consumption, Brand image

\section{Introduction}

Counterfeiting of famous luxury brands with a strong brand name and high-visibility is an ever growing global industry. Already in 1985 Business Week called counterfeiting "perhaps the world's fastest growing and most profitable business" and with more luxury brands with clearly externalized signs of recognition there are no indications that the industry is diminishing. Exactly how big the industry of counterfeit merchandise is is difficult to calculate exactly since it is an industry operating on a 'grey market'. One estimate is that counterfeiting accounts for more than $6 \%$ of worldwide trade or $\$ 450$ billion a year, and that some $\$ 100$ million worth of fake goods are seized each year entering the U.S. (Betts, 2004). The problem with counterfeit goods has become even more pressing for luxury brands with the entrance of the Internet as a new market actor. With professional looking websites, low prices, faster delivery times and wider range of delivery, the counterfeit merchandisers are posing a real threat to the luxury houses. The luxury houses are losing enormous amounts of money and are for example, responding by putting out the word that buying counterfeit products help support for instance terrorism and other not only illegal activities but also morally apprehensive. One dramatic example of counterfeiting leading to losses for brands is that of Louis Vuitton in the Italian market who in the late 1970s withdrew completely from the market when they found themselves unable to compete with the counterfeiters of their products (Kaikati \& LaGarce, 1980:58).

Suppliers of counterfeit merchandise have, like the luxury conglomerates, recognized the penetrative power of the Internet. The practice of counterfeiting has boomed with the possibility of selling on the Internet. The Internet enables the counterfeit merchandisers to reach consumers in all parts of the world. Having shipping all over the world with short delivery times and much lower prices than original goods. Also do not face the problem of being out of reach of mass consumption. A search on 'Rolex watch' renders 17900000 hits (December $3^{\text {rd }}$ 2011). Out of the hits a diminishingly small part are for sites with genuine merchandise. Counterfeiting is not a new phenomenon but with new sophisticated ways to reach consumers the business is increasing rapidly. The Internet offers an abundance of copies, counterfeits, replicas and otherwise knockoffs of luxury brand items. A search on the term 'Louis Vuitton bags' on Google renders 777000000 hits (December $3^{\text {rd }}$ 2011), most of them suppliers who offer counterfeit copies or as they call them 'replicas'.

Studies show that price and discounts are important factors for online shopping, this being the perfect argument for purchasing and selling counterfeits online. What happens when a new actor such as the Internet with the 
inherent connotations of low prices and wide distribution enters the market? Is the Internet better suited as a communications channel for luxury brands than as means for distribution? In order to investigate these questions this paper studies which 'values' that are prevailing in purchasing counterfeit merchandise online and what implications these would have on luxury brand image and consequently also on brand management.

\section{Literature Review}

While a brand imitation is designed so as to 'look like' and make consumers 'think of' the original brand, a counterfeit product is designed to 'be like' the original and provide consumers with a less expensive copy (d'Astous \& Gargouri, 2001:153). Counterfeiting has both a supply and a demand side and despite the supply-side efforts to reduce counterfeiting, the practice endures. In some areas, such as consumer fashion goods, counterfeiting appears to be increasing (Chute, 1990). According to Bloch, Bush and Campbell (1993:28) counterfeiting has flourished due to strong worldwide demand for high profile brands which carry a premium price and are easy to copy. This is consistent with Kapferer's (1997) point that luxury glitters and the fact that luxury is visible is essential: luxury must be seen, by the consumer and by others. That is why luxury brands externalise all of their signs: the brand signature must be seen and recognized on the person wearing the brand, and it must be recognized worldwide.

\subsection{Counterfeit Goods}

When purchasing a counterfeit good the consumer may or may not be a knowing and willing participant in the illegal practice. Grossman and Shapiro (1988) identified two types of counterfeiting; deceptive counterfeiting which is described as a situation in which the consumers are not aware of purchasing a counterfeit product at the time of the purchase. Consumers cannot readily observe the quality of the goods, nor can they easily distinguish copies from authentic merchandise. Grossman and Shapiro (1988) indicate that deceptive counterfeiting can be observed mainly in markets for automotive parts, consumer electronic products such as computers and stereo equipment, pharmaceuticals and medical devices. The luxury brand market however, often shows the other side, where consumers are involved in non-deceptive counterfeiting. In this situation consumers are fully aware of the fact that the product purchased is a counterfeit product at the time of purchase. Grossman and Shapiro (1988) describe that the public is well aware of the market availability of bogus brand-name watches, leather goods, fashion apparel, perfumes and designer sunglasses among others. They point to the fact that given this awareness and the fact that these fakes sell for a mere fraction of the cost of the legitimate products in outlets that are evidently not official distribution outlets, one can suspect that many buyers are not fooled. Grossman and Shapiro (1988) also pose the question on why a consumer would knowingly purchase a counterfeit item and give as one possible explanation that the product offers good value for money in light of its true quality or usefulness. They render this explanation insufficient because why incur the risks associated with illegal copying when legitimate products could be offered at a lower price. Instead they propose the alternative explanation that it is the label and identifying design characteristics (e.g. logo or distinctive fabric patterns) that are of value to consumers, such as the case is for status goods. In buying these types of counterfeit goods the risk is much smaller than with counterfeit goods that are technically advanced or of a medical nature. Counterfeit status goods often offer similar product qualities as the original merchandise and the consumer of this goods is not at any risk of bodily harm, or otherwise 'serious' risk. The consumers of these goods, however, subject themselves to social risk because the goods are of high symbolic value and social visibility (Nill \& Shultz, 1996).

Efforts of fighting counterfeiting practices come in many forms and Nill and Shultz (1996) propose that among conventional, supply-side remedies against counterfeiting, that include everything from diplomatic and legislative pressure to high-tech product labelling, some are effective while others are not and that because of this, company focus should also be on the consumer demand side of counterfeiting, with an emphasis on ethical consumer decision making.

\subsection{The Internet's Affects on Branding}

Shopping has become the fastest-growing use of the Internet, and almost 40 percent of Internet users report shopping as a primary use of the Web (GVU, 1998 in Donthu \& Garcia, 1999). Price comparison sites and shopping agents enable consumers to obtain and compare prices rapidly and put pressure on brand prices as lower price levels become more transparent (Sinha, 2000). Sinha (2000) sees the widespread availability of information about product prices, features and competitors on the Internet as posing a threat to brands. On a similar note, Sealy (1999) argues that brand management is out of date in today's markets where e.g. interactive marketing make traditional brand management less effective. As an argument for this point of view it is claimed that the greater choice and ability to compare products will make the information provided by brands redundant as the main function of a brand is an indicator of quality or some feature that differentiates the product or service 
from that of a competitor (Chen, 2001). A Study by USA Today shows that consumers who have not used the Internet to purchase goods and services claim to have used it for information searching that ultimately led to shopping in the traditional channels (USA Today, 1998 in Donthu \& Garcia, 1999). Price is commonly cited as being a key factor in purchase on the Internet (Chen, 2001). Donthu and Garcia (1999) in a study come to the conclusion that the typical Internet shopper is different from a typical Internet user. They, also find that the Internet shopper is no different from a non-shopper when it comes to brand and price consciousness. A study by marketing consultants Greenfield found that price was an extremely important factor in 60 per cent of purchases of clothing online. Chen (2001) identifies the main function of a brand as an indicator of quality or some feature that differentiates the product or services from that of a competitor. The Internet, providing consumers with a wealth of information about product quality, features and reliability, through online databases with reviews and ratings gives an ability to compare products. Chen (2001) makes the point that it is argued, that this greater choice and ability to compare products, makes information provided by brands redundant and that some evidence in support of this view is that price is commonly cited as being a key factor in purchase on the Internet. A study by marketing consultants Greenfield found that price was an extremely important factor in 60 per cent of purchases of clothing online (Activmedia, 2000), while a study by Cyberdialogue found that 79 per cent of shoppers reported that price discounts were important in drawing customers back to a website (Cyberdialogue, 2000). Attention has been devoted to examining the effects of a website on price sensitivity (Shankar et. al, 1998). Sinha (2000) sees cost transparency, made possible through the Internet, as the biggest threat for a company to brand its products and extract price premiums from buyers.

Sealy (1999) argues that major advances in marketing will depend on the broader use of information. The increased consumer power has been addressed by for example Ind and Riondino (2001) who state that not only does the Web give consumers far greater powers but it also extends the influence that customers have over each other. De Chernatony (2001) argues that Customers learn about brands through electronic conversations with other customers and brand owners need to listen and respond to these conversations. He proposes that by developing customer-welcomed enhancements brands will have some protection against the downward price spiral associated with great transparency (see. e.g. Sinha, 1999). In the luxury context, what could be said to be such customer welcomed enhancements? Luxury consumers see little or no problem with luxury brands having websites showing their merchandise but are less in favour of the possibility of online purchasing. The recognisability of the luxury products is accepted and even welcomed, but there is a fear of large distribution. The feeling of "me and a few more, but not everyone" is prevailing. Peterson (1997) produced a typology showing that the Internet may be an effective transaction and communication tool for luxury goods, because of their high cost, relatively low frequency of purchase, high value and high differentiation characteristics; this would mean that also counterfeit merchandise with high conspicuous and symbolic value could be sold online. But, on the other hand, since many luxury goods are experienced the Internet could function better as a tool for communication than transaction. According to Kapferer (2000), luxury brands, more than any other brand categories have a great deal to gain but also a great deal to fear from the Internet. The Web will give an opportunity to buy to those potential customers who do not have nearby access to one of the few distribution outlets of a luxury brand or who feel intimidated from entering "such temples of luxury". At the same time, for brands whose image is based on excellence and on highly selective distribution channels, there is a real threat of "commoditisation", arising from being referenced by other portals and being pirated by those who buy merchandise on the grey market.

\subsection{Luxury Online}

Lately brand marketers have found themselves needing to rethink their branding strategies in order to have both off-line (bricks and mortar environment) and on-line (clicks environment) (de Chernatony, 2001). Luxury brands are no exception to this new thinking. De Chernatony (2001) argues that a brand that exists in a bricks and mortar environment can be migrated to a clicks environment using the same brand essence, provided it remains true to the same values. This is for example seen on the luxury retailer eLuxury, belonging to the LVMH concerns, where Louis Vuitton has its' own separate web store. Louis Vuitton in the bricks and mortar environment has very selective distribution selling their products solely in their own boutiques which are strategically placed in key locations in larger cities. An online brand experience encompasses all points of interaction between the customer and the brand in the virtual space (Christodoulides \& de Chernatony, 2004:170). Rubinstein and Griffiths (2001:401) pointed out that “...on the Net you have to orchestrate everything you do to deliver a highly differentiated and consistent positive experience". Pine and Gilmore (1999:17) encouraged marketers to "create a brand image emphasizing the experience customers can have surrounding the purchase, use, or ownership of a good". Pine and Gilmore's encouragement of emphasizing 
experience fit in well with the consumption behaviour of luxury goods, with conspicuous consumption or competitive ostentation, the social experience is high in luxury consumption. Luxury goods are for consumers to a high degree created and 'experienced' in symbiosis with the company and the surrounding. Mitchell (2001) stated that: "...these "little things" - or "moments of truth", as some marketers call them - transform our understanding of brands. The brand is no longer the advertising of the product. The brand emerges from the sum total of real-life interactions between customer and company". Omanson et al. (2002:1) propose that "a critical consideration for companies is how to design their Web site to support the brand experience". Luxury goods stores have always been very distinct in both location and interior store design, as well as display of merchandise to enhance the luxury and exclusive experience, this is as important, if not more, online. On the luxury online website eLuxury who sells brands like, Dior, Marc Jacobs, Louis Vuitton etc., Louis Vuitton has its own online store, separated from the other brands, making the distinction between them and staying with its' original distribution policy of being sold exclusively in own brand boutiques only, not to be represented with other brands.

\section{Methodology and Findings}

The consumers in this study are engaged in purchasing non-deceptive counterfeit goods, i.e. they know that what they are purchasing are not originals. Online interviews, in the form of instant messaging and email have been conducted with 47 consumers of counterfeit merchandise, approximately $40 \%$ men and $60 \%$ women. The respondents were in the ages between 18 and 45. These consumers were found via websites selling counterfeit merchandise or otherwise known as 'replicas', where they had left messages on the website (two sites sold handbags and wallets and accessories and one sold watches). The messages posted on the website were so called 'testimonials', meaning that the consumers had left their opinion on the site and/or the merchandise sold there. Emails were sent out to all who had left an email address, asking them to participate in the study. The consumers interviewed are believed to have a positive pre-disposition towards 'fakes' and also toward internet shopping.

The empirical evidence is categorized into seven different related categories: (1) price; (2) information; (3) conspicuousness; (4) fear; (5) Quality - a hierarchy of fakes; (6) Substitutes; (7) Trading up.

Category 1: price: "I personally think that replicas are great. I myself purchased a few and have come to see that many times they are hard to even tell apart from an authentic piece. Yes, because sometimes certain items are so close to the quality of the real thing that I don't see why I shouldn't buy a replica that is so close in quality to the real thing." (Female respondent, 42 years-old)

"I don't think their is anything wrong with counterfeits I purchase them sometimes I own about 2 because they are cheaper and I don't have to worry about the emotional attachment I would have it were ever stolen."

Category 6: Substitutes: Many of the respondents express that they would like to buy original but the price of the genuine articles is the barrier. "Not a big fan of counterfeits. But being only 20 yrs old and a college student I do own one fake Louis Vuitton, but can hopefully buy a real one soon." (Female respondent, 20-years-old)

Category 7: Trading up: A number of the respondents expressed that they hade previously bought counterfeit merchandise but now feel that 'fakes' diminish and affect the image of originals. "I have to sadly admit, that I have purchased a replica Louis Vuitton bag as a placeholder while I saved up enough money to purchase a real version. I now feel that replicas are a lame attempt for people who would not otherwise be able to afford such an item to have it, and think that they are on the same platform as those that do buy the real thing. I no longer purchase them, and I feel that they de-value the original product. Most people that I know that can afford the real version feel the same, and would never purchase a "fake" item." (Female respondent, 32-years-old)

"Most fakes look really bad, they look very cheap and I would not want one and don't like when people have ugly fakes of something that I have the real thing. But there are some that look really good and I could see myself buying it because it is so very much cheaper." (Male respondent, 22-years-old)

In spite of a growing awareness of the illegality of counterfeiting and the luxury brands' efforts to change the perception of purchasing fakes only a few interviews show an awareness of the legal aspect. "I know that counterfeits or replicas are going against the law but the reason they are so appealing is that they look just like the originals and a very small percentage of the price." (female respondent, 28 years old)

It has shown that the respondents in most cases have in fact shopped counterfeits through traditional channels. The counterfeits are of different quality and are being ranked, word-of-mouth is very important; most of the consumers had been referred to the website by a friend or other who had previously purchased there. The fear that some consumers feel over shopping online is the same with these consumers. It is not the fact that they are purchasing 'fakes' that make some hesitant but that they are purchasing through the Internet. But they feel that 
the opportunity is too good to pass up.

The interviews conducted for this study have shown that price is one of the most important factors for consumers who purchase counterfeits online. The consumers show a tendency towards having purchased counterfeit luxury goods through traditional channels earlier and are now using the Internet as a complement. The internet is by these consumers used first and foremost as an information tool. Information coming not only from the counterfeiters' websites but also from the luxury brands' own websites. These are used by the consumers as 'point of reference' and pictures and descriptions are compared.

\section{Conclusions}

Two of the most important aspects of counterfeit luxury consumption online have shown to be brand visibility and price. The visibility aspect shows that the conspicuousness of consumption (Veblen, 1899) and audience reaction (Mason, 1984) are prevalent still today. The price aspect shows that studies done by for example Sinha (2000) can be applied also to luxury goods. That price is of high significance means that counterfeits have a great deal of market share to gain through online sales.

The view of a consumer as economic and that of a luxury consumer seems are on opposite sides of the spectrum. Luxury consumption per definition is a non-functional demand and can thus not be seen as economic. On the contrary luxury consumption seems to defy the 'economic man' thinking. A rational perspective towards shopping can be defined as "a view of the consumer as a careful analytical decision-maker who tries to maximize utility in purchase decisions" (Solomon, Bamossy \& Askegaard, 2002:588) and according to this perspective "people calmly and carefully integrate as much information as possible with what they already know about a product, painstakingly weigh the pluses and minuses of each alternative, and arrive at a satisfactory decision" (pp.235-236). This paper proposes that consumer of counterfeit luxury goods online are both rational and economical, while at the same time symbolic and conspicuous.

The luxury brands own websites are a help in the purchasing of 'fake' products serving as a point of reference, i.e. comparing brand logos and such before purchasing a counterfeit item, in order to make sure that it is as close to resembling the real artefact as possible. Luxury brands should consistently continue to inform consumers as well as potential consumer on where they can purchase genuine luxury goods. This might not get the consumer of counterfeit goods to buy original but it will reduce the risk of someone being deceived by a site. This will also give consumers of genuine merchandise the feel good about themselves, post-purchase feelings, re-assuring them that they have made the right choice in purchasing the genuine product.

\section{References}

Betts, K. (2004). The purse-party blues. Time, Vol. 164, Issue 5, 68-70.

Bush, R.F., Bloch, P.H., and Campbell, L. (1993). Consumer Acomplices in Product Counterfeiting - A demand side investigation. Journal of Consumer Marketing, Vol. 10, No. 4, 27-36. http://dx.doi.org/10.1108/07363769310047374

Bush, R.F., Bloch, P.H., and Dawson, S. (1989). Remedies for Product Counterfeiting. Business Horizons (January/February), 59-65.

Catry, B. (2003). The Great Pretenders: The magic of luxury goods. Business Strategy Review, Vol. 14, Issue 3, 10-17. http://dx.doi.org/10.1111/1467-8616.00267

Christodoulides, G., and de Chernatony, L. (2004). Dimensionalising on- and offline brands' composite equity. Journal of Product and Brand Management, Vol. 13, No. 3, 168-179. http://dx.doi.org/10.1108/10610420410538069

Cordell, V.V., Wongtada, N., and Kieshcnick, R.L. (1996). Counterfeit purchase intentions: role of lawfulness attitudes and product traits as determinants. Journal of Business Research, Vol. 35, (1), 41-53. http://dx.doi.org/10.1016/0148-2963(95)00009-7

De Chernatony, L. (2001). Succeeding with brands on the Internet. Journal of Brand Management, Vol. 8, No. 3, 186-95. http://dx.doi.org/10.1057/palgrave.bm.2540019

Dubois, B., and Paternault, C. (1995). Observations: understanding the world of international luxury brands: The "dream formula". Journal of Advertising Research, Vol. 35, No 4, 69-76.

Grossman, G.M., and Shapiro, C. (1988a). Foreign counterfeiting of status goods. The Quarterly Journal of Economics, Issue 1, (February), 79-100. http://dx.doi.org/10.2307/1882643

Grossman, G.M., and Shapiro, C. (1988b). Counterfeit-product trade. The American Economic Review, Vol. 78, 
Issue 1, (March), 59-75.

Ind, N., and Riondino, M.C. (2001). Branding on the Web: a real revolution? Journal of Brand Management, Vol. 9, No. 1, 8-19. http://dx.doi.org/10.1057/palgrave.bm.2540048

Kapferer, J.N. (1997). Managing luxury brands. Journal of Brand Management, Vol. 4, No. 4, 251-60.

Kapferer, J.N. (2000). How the Internet impacts on brand management. Journal of Brand Management, Vol. 7, No. 6, 389-91.

Omanson, R.C., Cline, J.A., \& Nordhielm, C.L. (2002). Effects of Visual Consistency on the Online Brand Experience. J.W. Kellogg Graduate School of Management, Evanston, IL.

Solomon, M., Bamossy, G., \& Askegaard, S. (2002). Consumer Behaviour: A European Perspective (2nd edition). Harlow UK, FT Prentice Hall. 